\title{
マグネシウム・ダイカスト製品の熱的性質と 機械的性質についで
}

Seita Sakui and Hiroshi Onoda: The 'Thermal Characteristics and Mechanical Properties of Magnesium Die Cast Specimens. (On the Characteristics of Magnesium Die Casting, 2nd Report). Concerning the three kinds of conventionally used diecasting alloys ( $\mathrm{Mg}_{-}, \mathrm{Al}$-and $\mathrm{Zn}$ alloys), we have studied (a) the relation between the temperature of specimens that are ejected from the die and the shot numbers, and (b) the tensile properties and the impact value of specimen at room- and high temperature, with due reference to the shot numbers. By these investigations, the following distinctive features of $\mathrm{Mg}$ alloys were found in comparison with those of the other two alloys: (1) The temperature of dies has a strong influence on that of $\mathrm{Mg}$-alloy castings. (2) The mechanical properties of $\mathrm{Mg}$-alloy castings are inferior to those of Al-and $\mathrm{Zn}$ alloys. (3) The deformation of castings caused by the ejector pin is mildest in $\mathrm{Mg}$ alloys, judging from the strength of castings at high temperature and the casting temperature. (4) It was also ascertained that the heat-loss of the dies varies proportionally to the temperature of the dies.

(Received August 4, 1959)

\section{I.はしがき}

第 1 報では金型の熱的特性を中心として Mg 合金ダイカ ストが在来の $\mathrm{A} 1$ 合金㘧よび $\mathrm{Zn}$ 合金ダイカストと異なる 点を明らかにしたが，今回は製品の熱的特性および金型温 度，製品温度，製品の機械的性質の三者の関連について調 ベた結果を述べこれより $\mathrm{Mg}$ 合金ダイカストの特長を明
各測定点の平均を求めずに上限に近いところに実線を引い たのは測定法の不備のために製品は冷却して実際の表面温 度より低心值しか得られず, 稀に高い値を得たとすればそ れが比較的に真に近い,值になるうと推定したのである.

$\mathrm{Mg}$ 合金では測定点の分散が甚だしいが，Zn 合金ではそれ が比較的によく揃らのは各 くの合金の熱容量の大小で説明

Table 1 Heat balance in die-casting technique with same typical alloys.

\begin{tabular}{|c|c|c|c|c|c|c|}
\hline & $\left|\begin{array}{c}\text { Temperature of } \\
\text { molten metal } \\
\left({ }^{\circ} \mathrm{C}\right)\end{array}\right|$ & $\begin{array}{c}\text { Saturated die } \\
\text { temperature } \\
\left({ }^{\circ} \mathrm{C}\right)\end{array}$ & $\begin{array}{l}\text { Saturated tem- } \\
\text { perature of pro- } \\
\text { duct }\left({ }^{\circ} \mathrm{C}\right)\end{array}$ & $\begin{array}{l}\text { Heat content of } \\
\text { molten metal } \\
\text { (calorie/shot) }\end{array}$ & $\left|\begin{array}{c}\text { Heat content of } \\
\text { product } \\
\text { (calorie) }\end{array}\right|$ & $\begin{array}{c}\text { Heat loss from } \\
\text { die } \\
\text { (calorie) } \\
\end{array}$ \\
\hline AZ91A & $\begin{array}{l}600 \\
640 \\
680\end{array}$ & $\begin{array}{l}155 \\
160 \\
175\end{array}$ & $\begin{array}{l}180 \\
170 \\
180 \\
\end{array}$ & $\begin{array}{l}6120 \\
6350 \\
6890 \\
\end{array}$ & $\begin{array}{l}1550 \\
1460 \\
1550 \\
\end{array}$ & $\begin{array}{l}4570 \\
4890 \\
5340 \\
\end{array}$ \\
\hline Silumin & $\begin{array}{l}600 \\
640 \\
680\end{array}$ & $\begin{array}{l}200 \\
215 \\
220\end{array}$ & $\begin{array}{l}260 \\
280 \\
280\end{array}$ & $\begin{array}{l}8280 \\
8650 \\
9070 \\
\end{array}$ & $\begin{array}{l}2060 \\
2220 \\
2220\end{array}$ & $\begin{array}{l}6220 \\
6430 \\
6850 \\
\end{array}$ \\
\hline ZAC No.1 & $\begin{array}{l}420 \\
500 \\
\end{array}$ & $\begin{array}{l}155 \\
165\end{array}$ & $\begin{array}{l}180 \\
190 \\
\end{array}$ & $\begin{array}{l}6100 \\
7050 \\
\end{array}$ & $\begin{array}{l}1560 \\
1650\end{array}$ & $\begin{array}{l}4540 \\
5400 \\
\end{array}$ \\
\hline $\mathrm{Pb}$ alloy & 320 & 84 & 78 & 2310 & 350 & 1960 \\
\hline $\mathrm{Sn}$ & 300 & 102 & 96 & 3255 & 550 & 2705 \\
\hline
\end{tabular}

らかにした。

\section{II. 製品の温度について}

第 1 報と全然同じ金型で小型の試片を鋳造し，金型から 取出した試片は数秒以内にその表面温度を接触型の表面温 度計で測定した。その結果はTable 1 に示す如く Zn 合 金の製品の平衡温度は略 $2 \mathrm{Mg}$ 合金のそれに等しく, $\mathrm{A} 1$ 合 金では最高である. Fig.1,2,3は製品温度とショット数と の関係を示す・測定点はかなり分散しているがこれは温度 計の製品表面への接触が仲々一様にいかず，また金型から

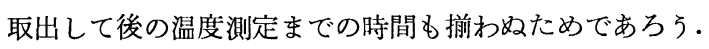

** 東京工業大学

* 1959 年 4 月本会東京大会に発表; マグネシウムダイ カストの特性に関する研究 (第 2 報)

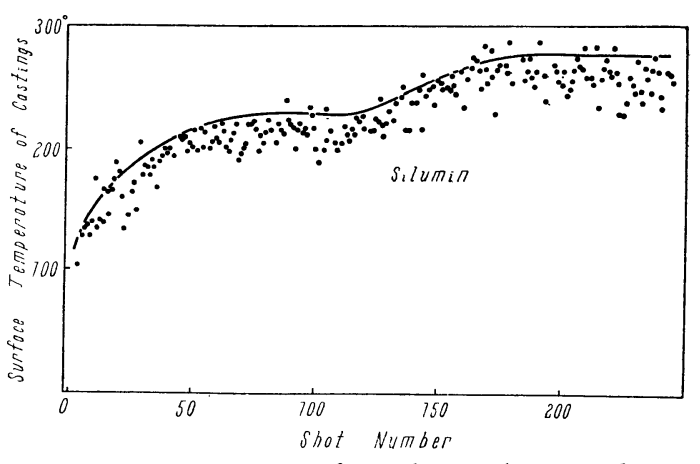

Fig.1 Temperature of products-shot number curve.

できよう・

これらの曲線で興味があるのは金型温度が常温の時の製 
品温度と，金型温度が平衡温度に達した時の製品温度との 羑である. $\mathrm{Mg}$ 合金では $130^{\circ}$ の上昇を示し 約 $325 \%$ の上

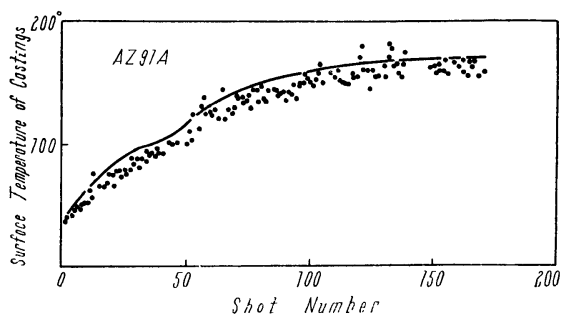

Fig.2 The same as Fig.1.

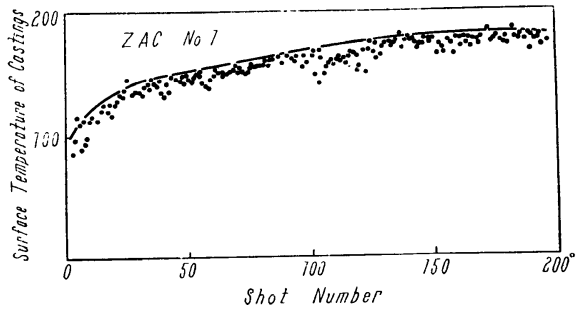

Fig.3 The same as Fig.2. 昇洎で あり, A1 合 金で は $150^{\circ}$, $115 \%$, $\mathrm{Zn}$ 合 金 では80 $80 \%$ の上 界を示し ている。 このよう な差異も 矢張り合 金の熱容 量の大小 で説明が つく．金型温度の如何によつて製品が金型に奪われる熱量 は変化するが，それに伴う製品温度の变化は熱容量の小な る製品ではげしいことは当然であろ5. 以上の事実から $\mathrm{Mg}$ 合金の製品の温度は金型温度の影響を受けることが甚 だしいので，製品の性質を保つためには金型温度を一定に 保つ必要が大で, その点では Zn 合金, A1 合金よりも難か しい合金であるように見える。

飽和した金型温度および製品温度に対する熔湯温度の影 響を示したのが Fig.4である。この両者が愹湯温度の.上

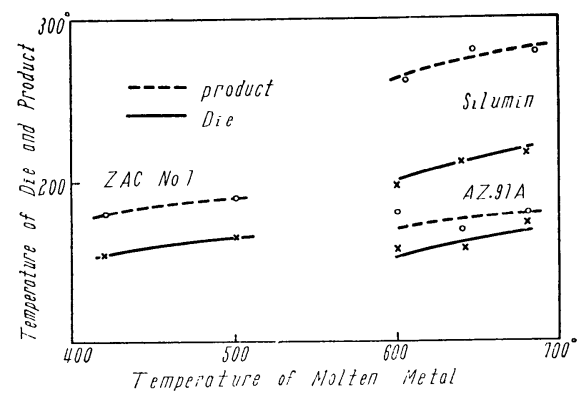

Fig. 4 Relation between temperature of molten metal and temperature of die and product.
昇に伴つ

て高くな

ることは 当然であ るが,そ の他に製 品温度と 金型温度 との差が 各合金で 異なるこ とが一目

で判る. $\mathrm{Mg}$ 合金は鋳造の間に持てる熱量を殆んど叫き出 し金型温度に近ついた形であり，A1 合金は $\mathrm{Mg}$ 合金と殆 んど同量の熱量を吐き出した後にもなお多くの熱量を保持 し，金型に対して自身の高温を維持しているのであろ 5 .

\section{III. 金型よりの熱損失について}

多数のショットの後に金型が平衡温度に達した時には， 金型に入る熱量と金型より出る熱量とは等しくなる*. 熔 湯の持つ熱量を $Q_{0}$ ，製品が持つて逃げる熱量を $Q_{1}$ ，熔湯

* 椺田: 軽 金属, 26(1957),55; 和田：精密鋳造, 1 (1956) , 152 .

から金型に移動する熱量を $Q_{2}$ とすると

$$
Q_{0}=Q_{1}+Q_{2}, \quad \therefore Q_{2}=Q_{0}-Q_{1}
$$

この式から $Q_{2}$, 従つて金型から外部へ逃れ去る熱量を知 ることができる. 本実験の 3 合金についての $Q_{0}$ および $Q_{1}$ の值を Table 1 に示す.これより我々は金型の平衡温度 と金型からの熱損失 $Q_{2}$ との関係を求めることができる.

Fig.5によれば両者の関係は直線的である。これはもちろ 儿本実験に使用した特定の金型を 水冷せずに 25 秒間隔で 鋳造した時の特性を示すもので。これらの条件が変ればま た別の関倸が生ずるものである．実用されている各種の金

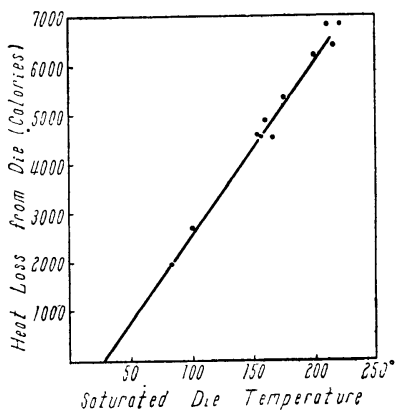

Fig.5 Relation between heat loss from die and saturated die temperature.
型でこの関係を測定する ことは興味ある研究題目 である・Fig.5から本実 駼の金型では金型の平衡 温度は金型が製品から受 取る熱量に比例している ことが明らかである。

本実験では金型の平衡 温度を測定すれば Fig. 5 により $Q_{2}$ を知りそれよ り製品の温度を知ること がでさるし，逆に製品の 平衡温度から金型のそれを推定することも可能である.

\section{IV. 製品の機械的性犋について}

\section{1. 引張試験}

Fig.1,2,3などに示した金型の平衡温度に対応して製品 の機械的性質がどのように変化するかを見るために，製品

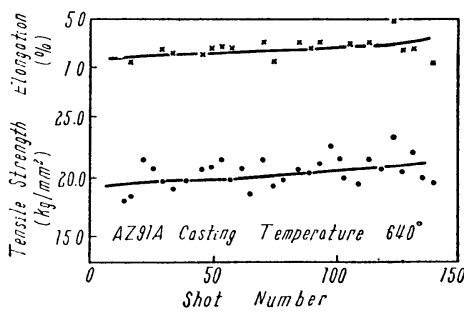

Fig.6 Relation between tensile strength or elongation and shot number.

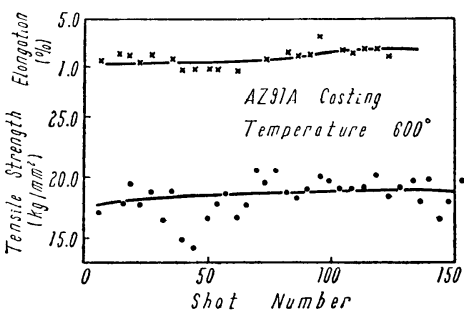

Fig.7 The same as Fig. 6 . の機械的性質とシ ヨット数との関係 を Fig.6以下に示 す. 最初に引張試 験の結果について 検討する.

(1) $\mathrm{Mg}$ 合金

Fig.6, 7 は $\mathrm{Mg}$ 合金に括ける引張 試験の 結果であ る.これによれば 引張強度と伸びは 共にショット数の 增加に伴つて增加 している.10ショ ット目と 150 ショ ット目のこれらの 性質を比較すると伸びの増加は著しく約 $100 \%$ の増加であ るが引張強度は $16 \%$ の増加である．伸びが顕著に増加し さらに増加を続ける形であるから，150ショットにおける 金型温度の $160^{\circ}$ は低きに失していると考らべきで巷間と 
なえられている $200^{\circ}$ 以上が良好な結果を示すのであろう. 次に熔湯温度の影響を見るに, $640^{\circ}$ と $680^{\circ}$ では上記の諸性

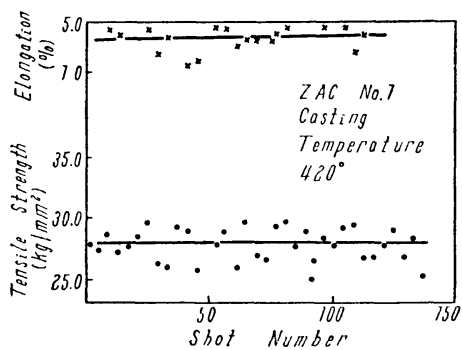

Fig.8 The same as Fig.7.
質に対する効果に 殆んど差異はない が, $600^{\circ}$ の熔湯温 度では明らかに伸 び, 引張強度共に 劣化してこの温度 の不適当なことを 示している.

(2) Zn 合金

Fig.8,9に示す如く引張性質に対するショット数の影響 は殆んどない。これは製品温度が金型温度に左右されない

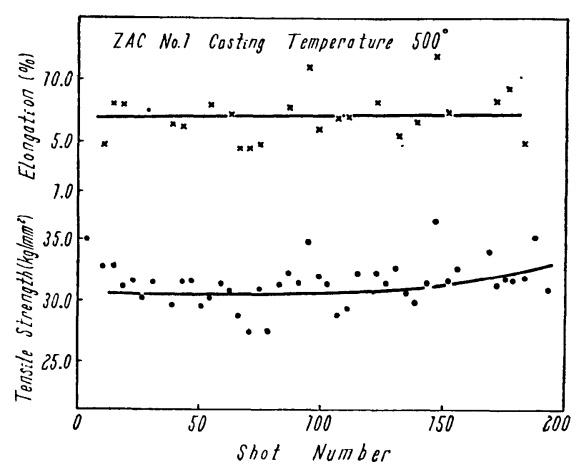

Fig.9 The same as Fig.8.
といら上 記の事実 によるも のであろ 了. 熔湯 温度の影 響は顕著 で $420^{\circ}$ の 時に比へ て500の 場合は伸 びは約 $85 \%$, 引張強度は $18 \%$ の増加を来たしている.

\section{(3) A1 合金}

$\mathrm{A} 1$ 合金製品の引張強度, 伸びも Fig.10,11,12 に示す如 く殆んど型温の影響を受けない. Fig.11の如く金型温度が 上昇するとやや強度が低下して伸びが増加する傾向のもの もある.ただ引張強度の測定値が著しく散乱しているのが 目立つ. 伸びの測定值は比較的によく揃つているように見 えるが，これはその值が $2 \%$ 前後の小さいものであるため

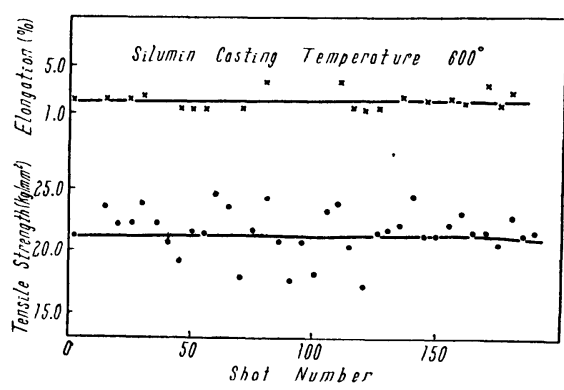

Fig.10 The same as Fig.9.
であろ 5. 熔湯 温度の影 響として は $600^{\circ} の$ ものが他 の $640^{\circ}$, $680^{\circ}$ のむ のに比し て強度, 伸び共に劣り，この温度が不適当なことを物語つている.

\section{（4）パーナー加熱による実験}

以上は普通の操業の如くに連続的に 25 秒間隔で鋳造し た場合であるが，さらに高い金型温度に拈いては機械的性 質が改善されるのではないかと考えて, 常温の金型表面を ガスバーナーで加熱し希望温度に達すると直ちに鋳造する
実験を行つた・一つの希望温度に対して常に室温から急速 に加熱して行くことにした.

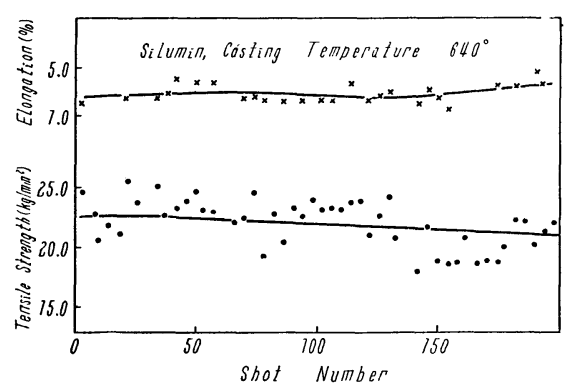

Fig.11 The same as Fig.10

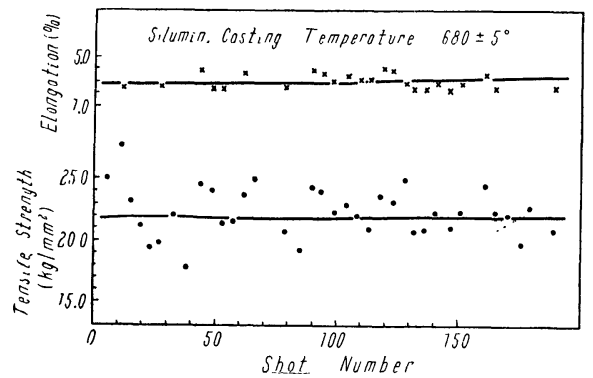

これら の試片に ついて引 張強度を 調ベたの が Fig. 13 であ る. 各曲 線に附し た矢印は 前述の連 続鋳造作 業に打け る平衡温 度を示 寸. $\mathrm{Zn}$ 合 金以外で は $50^{\circ}$ か

Fig.12 The same as Fig.11.
温度までの変化は上記の曲線の傾向と一致する. Zn 合金 の場合何故に上記と著しい差異が見られるのかは判らない が，多分今回の如き急速加熱では金型の表面のみが過熱さ れ金型内部は温度上䄯せず急激な温度勾配を生じており， 金型のチル効果が大きいためであろう．3 種類の合金につ いて顕微鏡組織の検査の結果は $\mathrm{Zn}$ 合金では柱状の 樹状晶 から成るチル層の発達が著しく, $\mathrm{A} 1$ 合金のチル層の厚さは $\mathrm{Zn}$ 合金の $1 / 3$ の程度であり $\mathrm{Mg}$ 合金にはチル層は見られ ない(紙面の都合で写真は省略)．また $\mathrm{Zn}$ 合金のチル層の 厚さが金型温度で顕著に変化する有様は別の報告で述べる が, 金型温度の低い時にはチル層の発達著しく, 薄肉鋳物

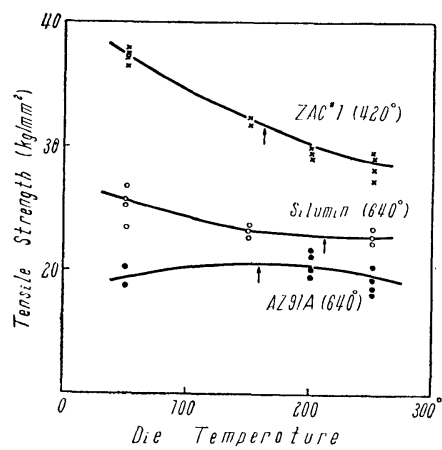

Fig.13 Relation between die temperature and tensile strength.
ではこのため引張強 度が著しく增加する と考えると Fig.13 の説明はつく. Mg合 金で引張強度があま り金型に左右されな い原因むわかる。こ れらはあくまでバー ナーで急熱の特殊な る場合で普通操業で は (4) 項以外で述べ ていることの方が実 際的であろう.
以上を要約すると $\mathrm{Mg}$ 合金の引張強度は他の 2 合金に比 ベると低くく，伸びは $\mathrm{A} 1$ 合金と同程度で共に $\mathrm{Zn}$ 合金に比 ぺて低い. 熔湯温度の低過ぎるのは引張性質に対して悪影 響がある・ 


\section{2. 街繋試験}

本実験の板状試片を $2 \mathrm{~kg}-\mathrm{m}$ 容量の小型シャルピー衝撃

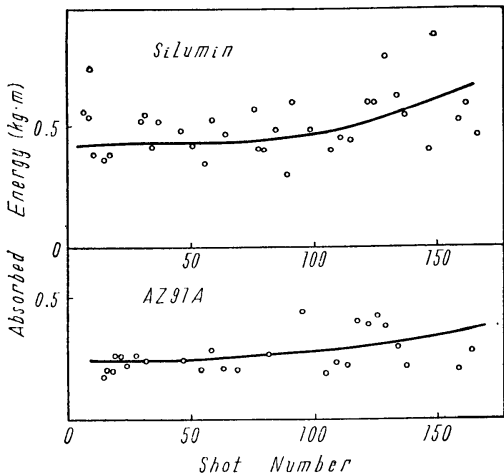

Fig.14 Impact value of specimensshot number curve.

試験機で試 験の結果は

Fig.14 に示 す如くであ る. 振子は試 片板面に直角 に当るよ 5 に 試片を取りつ けた.ダイカ スト製品が動 的荷重を受け る場合, とく に薄肉壁面の場合を考えると，この種の試験を行つておく 必要がある. 3 種類の合金の中, Zn 合金は破断せずに塑 性的に曲がつてしまい吸収エネルギーの測定はできなかつ た. $\mathrm{Mg}$ 合金䘛よび $\mathrm{A} 1$ 合金では因の如く, Mg 合金は $\mathrm{A} 1$ 合 金に比べると遙かに小さな衝撃値を示している.この衝撃 試験の間に扣ける時間一荷重曲線を振子て附した水晶と陰 極線オシログラフの系で測定した一例は Fig.15に示す.
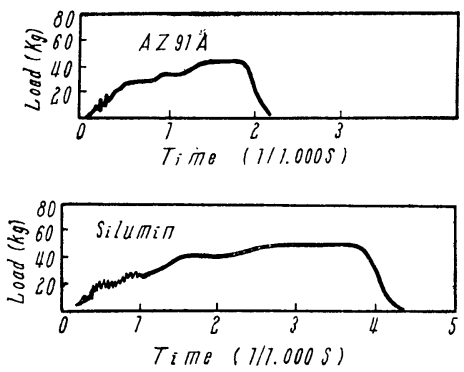

Fig.15 Load-time curve at impact test.

$\mathrm{Mg}$ 合金は最大荷 重 $40 \mathrm{~kg}$ 程度, 破 断までの時間は 0.0021 秒の程度 であるが, Al 合金 では $52 \mathrm{~kg}$ 前後, 0.0045 秒であり， 破断の際の荷重 降下む $\mathrm{Mg}$ 合金 に比べて緩やかで 靶性の多いことを示している。このよ5に Mg 合金は吸収 エネルギーも $\mathrm{A} 1$ 合金より少く，その荷重一時間曲線も $\mathrm{A} 1$ 合金より劣り, 靶性は少いといわねばならない。衝撃荷重 に対して Zn 合金は最も安全といえよう。また衝撃值が金 型温度の上昇と共に向上しているのも與味が深い。ことに その向上が $\mathrm{A} 1$ 合金著しいのは多分脆いチル層が 金型温 度の上䄯に伴つて減少するためであろう。

\section{3. 高温引張強度および俖びの測定}

一一般に鋳造つ際に鋳造残留応力の生ずるのはある臨界温 度以下に拈り万垷象であつて, 試片の強度が熱応力および 变態応力に充分に堪え 5 るほど大になる时期である.この 意味で臨界温度は高温強度の大きいものほど高く, 上記の 残留応力発生の機会は大きい. ダイカストの場合も同様で あろう。この他ダイカスト特有の事柄として押出ピンで製 品を金型から押出与作業がある。これは上記の如く相当の 高温であり製品の高温強度の小なる時は歪を生ずる恐れが ある、また製品自体が高温で使用されることもある。いろ いろの点で高温強度を知つて执くことが大切で, Fig.16,
17 はそれぞれ高温に拈ける引張強度执よび伸びを示した ものである.

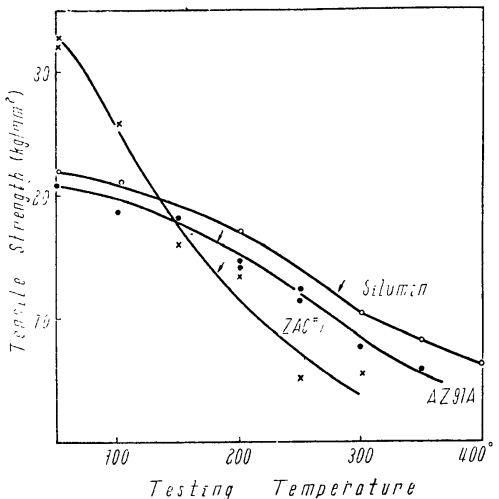

Fig.16 Tensile strength of specimens at high temperature.
これによれば $\mathrm{Zn}$ 合金は温度 と共に急激に強 度減少, 伸び增 加を示していて $\mathrm{Zn}$ 合金は残留 応力は生じ難い が, 矢印の温度 での押出しでは 押出ピンによる 歪の生じ易いこ とを示してい る. $\mathrm{Mg}$ 合金,
$\mathrm{Al}$ 合金は略 2 同様な傾向を示すが，いずれも Zn 合金より は残留応力が発生し易そうである。ただ $\mathrm{Mg}$ 合金製品の離 型時の温度が知印の如く低いので，押出ピンによる歪は少 いと思われる．その点 $\mathrm{A} 1$ 合金は離型時の温度高くそのた め強度は $\mathrm{Zn}$ 合金よりも低く押出ピンによる变形を研究し なければならない。
V. 総括

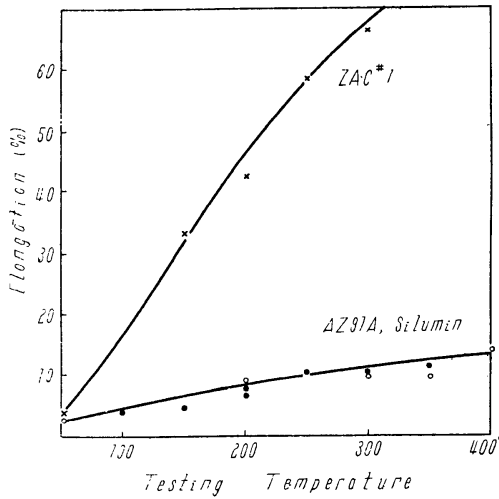

Fig.17 Influence of temperature on elongation.
3 種類の合金 についてダイカ スト製品を金型 から取出す時の 製品温度を测定 し, 製品温度と 製品の機械的性 質の関係を考察 した.これらの 考察に沶いて $\mathrm{Mg}$ 合金が他の 2 合金と如何な る点が相違する かを考察した。

(1) 製品温度が金型温度に支配される程度は Mg 合金に おけて最大で Zn 合金で最小である。（2）本実験の金型で は金型よりの熱損失は金型の表面温度に正比例することが 明らかになつた。（3）各合金共に，熔湯温度が低きに失す る時は機械的性質は明らか儿劣化する。（4）金型温度つ機 械的性質に対する影響はガス・バーナーで金型を急熱した 時と普通つ連続作業の場合とでは異なる。（5) 薄板状試片 では衝撃値は $\mathrm{Mg}$ 合金は $\mathrm{Al}$ 合金に比べて著しく低い。そ の事実の内容を衝撃時の荷重一時間曲線で説明した。

（6）製品の高温強度を測定した．押出ピンによる変形は $\mathrm{Mg}$ 合金で最も少いと推定された.

今回の実験に試料用地金について御援助を頂いた三井金 属鈗山株式会社, 古河マグネシウム株式会社に感謝の意を 表します。 